\title{
CHEMICAL COMPOSITION AND SIZE DISTRIBUTION OF FINE AEROSOL PARTICLES ON THE EAST COAST OF THE BALTIC SEA
}

\author{
I. Rimšelytė ${ }^{\mathrm{a}}$, J. Ovadnevaite ${ }^{\mathrm{a}}$, D. Čeburnis ${ }^{\mathrm{a}, \mathrm{b}}, \mathrm{K}$. Kvietkus ${ }^{\mathrm{a}}$, and E. Pesliakaite ${ }^{\mathrm{a}}$ \\ ${ }^{a}$ Institute of Physics, Savanoriu 231, LT-02300 Vilnius, Lithuania \\ E-mail: ingar@ar.fi.lt \\ ${ }^{\mathrm{b}}$ Department of Experimental Physics \& Environmental Change Institute, National University of Ireland, University Road, \\ Galway, Ireland
}

Received 20 June 2007; accepted 21 November 2007

\begin{abstract}
The size distribution and chemical composition of ambient aerosol particles (PM1) were measured using an Aerodyne aerosol mass spectrometer (AMS) at the Preila air pollution research station on 3-15 September, 2006. The major observed components of aerosol particles were sulfate and organic matter with a smaller amount of nitrate and ammonium. Large contribution of organic matter was established in all air masses, however it reached $60 \%$ of the total aerosol particle mass in the North Atlantic marine air masses. The analysis of size distribution spectra enabled us to explain the origin of aerosol chemical components. In relatively clear North Atlantic air mass, mainly two modes were registered both for sulfate and organic matter - one in the submicron range, the other in the supermicron range. The diameter of sulfate-containing particles in the accumulation mode differed from that of organic-containing particles; they were about 270 and $170 \mathrm{~nm}$, respectively. This difference showed different sources or transformation mechanisms of sulfate and organic compounds. In polluted air masses, the anthropogenic origin of both components was dominant, thus diameters in accumulation mode became equal and were about $400 \mathrm{~nm}$, showing a dominant secondary production mechanism.
\end{abstract}

Keywords: aerosol composition, size distribution, aerosol mass spectrometer

PACS: 92.60.Mt, 92,60.Sz, 92.20.Bk

\section{Introduction}

Atmospheric aerosols from a wide variety of emission sources are receiving increased attention because of their influence on human health [1], visibility, acid deposition, and global climate [2]. The direct effect of aerosols on the climate is the change in radiative forcing through absorption and reflection of solar radiation. Aerosols also affect the regional climate as cloud condensation nuclei $(\mathrm{CCN})$, which determine properties, the evolution, and development of precipitation [3]. In both cases, chemical composition plays an important role as the determinant of aerosol optical properties and the efficiency of cloud formation. Especially, organic compounds are regarded as important CCN [4]. Organic material significantly contributes to the total fine aerosol particle mass at continental mid-latitudes, $\sim 20-50 \%[5,6]$ and almost $90 \%$ in tropical forested areas [7]. The recent publication demonstrated that significant portion of marine aerosol consisted of organic compounds and contributed $63 \%$ to the sub-micrometer aerosol particle mass during the period of high biological activity in the North Atlantic [8].

Organic compounds in the atmosphere in a particulate form are both emitted directly (primary organic aerosol particles) and formed through photochemical oxidation of reactive organic gases. Under certain conditions, atmospheric reaction products can nucleate to form new particles. Both biogenic and anthropogenic sources contribute to the primary and secondary organic aerosol particles and can be a major contributor to the fine aerosol particles [9].

The chemical complexity and labile nature of atmospheric particulate matter (PM) strongly favour realtime instrumental analysis techniques that characterize pertinent physical and chemical properties without having to collect, store, and transport samples. Real-time instruments that measure physical properties such as particle number densities, mass loadings, and particle mobility or aerodynamic size distributions have been available for some time [10]. However, real-time instruments that characterize the chemical composition 


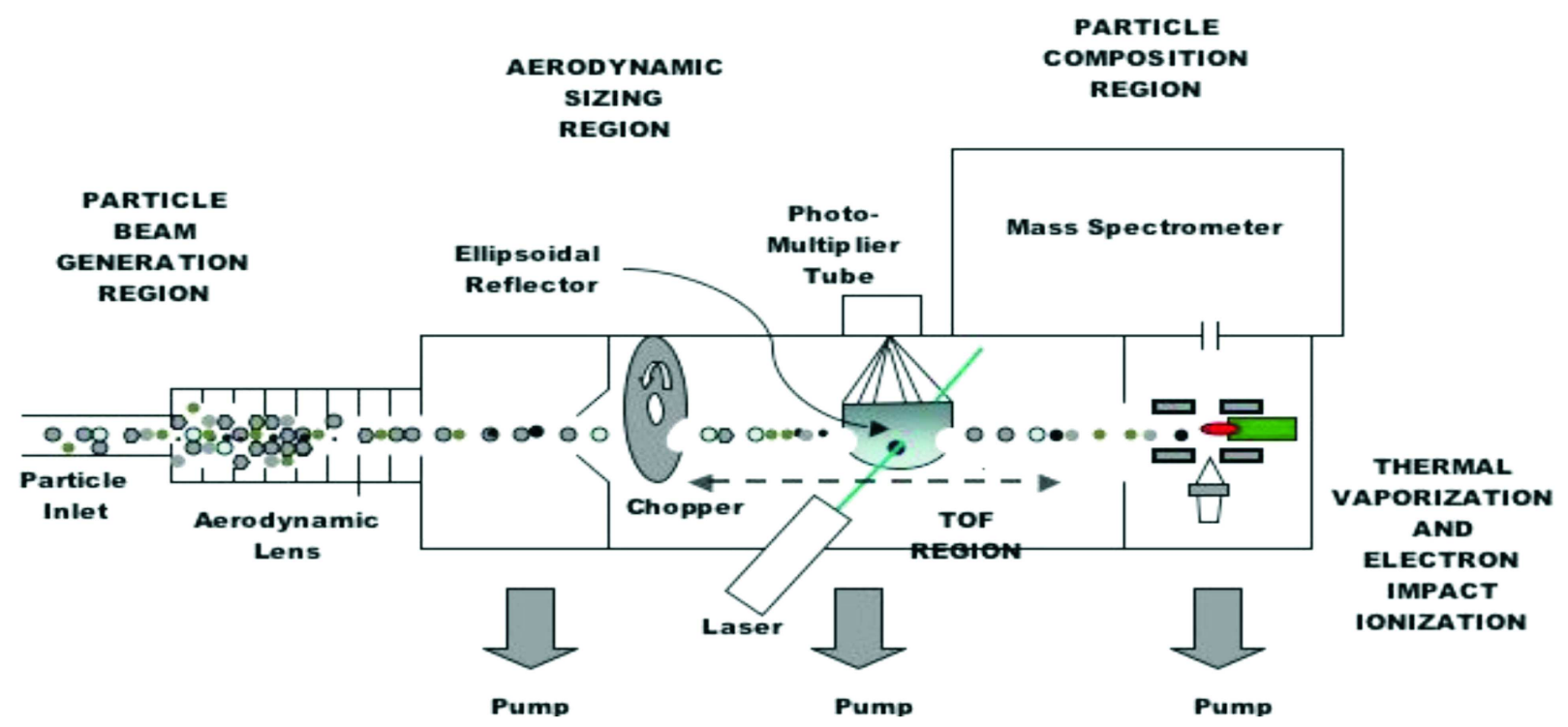

Fig. 1. Scheme of the aerosol mass spectrometer.

of atmospheric PM, ideally as a function of particle size, are a more recent development.

The aim of this study was to analyse the dependence of the aerosol particle size distribution and chemical composition in different air masses on the east coast of the Baltic Sea.

\section{Experimental methods}

\subsection{Site description}

The measurements were performed at the Preila air pollution research station on 3-15 September, 2006. The air pollution research station $\left(55^{\circ} 55^{\prime} \mathrm{N}\right.$ and $21^{\circ} 00^{\prime} \mathrm{E}, 5 \mathrm{~m}$ a.s.l. - above sea level) is located in western Lithuania on the coast of the Baltic Sea, on the Curonian Spit. The Curonian Spit is a narrow sandy peninsula (0.4-4.0 km in width), which separates the Baltic Sea from the Curonian Lagoon. The main local sources of pollution at this station might be Preila village (300 inhabitants) at a $2.5 \mathrm{~km}$ distance to the east, a small town of Nida (2700 inhabitants) at a $6 \mathrm{~km}$ distance to the south, and the road Klaipeda-Kaliningrad at a distance of $300 \mathrm{~m}$ to the east of the monitoring station. One of the nearest industrial cities, Klaipeda, is at a distance of about $40 \mathrm{~km}$ to the north, and the other major city, Kaliningrad, is $90 \mathrm{~km}$ to south from the site.

\subsection{Instruments}

An aerosol mass spectrometer (AMS), developed at Aerodyne Research, was used to obtain real-time quantitative information on particle size-resolved mass load- ings for volatile and semi-volatile chemical components present in/on ambient aerosol. The AMS does not efficiently detect low-volatility materials such as black carbon, $\mathrm{NaCl}$, crustal oxides, and certain metals. It provides quantitative composition information on ensembles of particles with limited single-particle information. The instrument combines standard vacuum and mass spectrometric techniques with aerosol sampling techniques. A schematic diagram of the AMS is presented in Fig. 1.

Aerosols enter the instrument through a sampling inlet that restricts the flow with a $100 \mu \mathrm{m}$ (or similar diameter) critical orifice and then through an aerodynamic lens $[11,12]$, which focuses the aerosols into a tight beam using 6 apertures while removing most of the atmospheric gas. As the aerosols exit the lens, they are accelerated by supersonic expansion caused by the difference in pressure between the sampling and sizing chambers, which imparts different velocities to aerosols of different sizes. After passing through the lens, the aerosols enter the particle sizing chamber. A rotating chopper wheel, with two radial slits located $180^{\circ}$ apart, intercepts the focused particle beam. The chopper can be placed in any of three positions: completely blocking the beam so that no particles pass through (beam closed); not blocking the beam so that all particles pass through (beam open), and a chopping position that allows particles to pass through the radial slits only (beam chopped). There are two modes of operation, the time-of-flight (TOF) mode and the mass spectrometer (MS) mode. The time of flight of particles between the chopper and the detector is the measure of their velocity, and from this measurement 
the particle aerodynamic diameter ( $\left.D_{\text {aero }}\right)$ can be determined. In the MS mode, particles fly unimpeded until they impact on a resistively heated surface where the volatile and semi-volatile portions of aerosols are vaporized and then immediately ionized by the electron impact $(70 \mathrm{eV})$. A standard quadrupole mass spectrom-

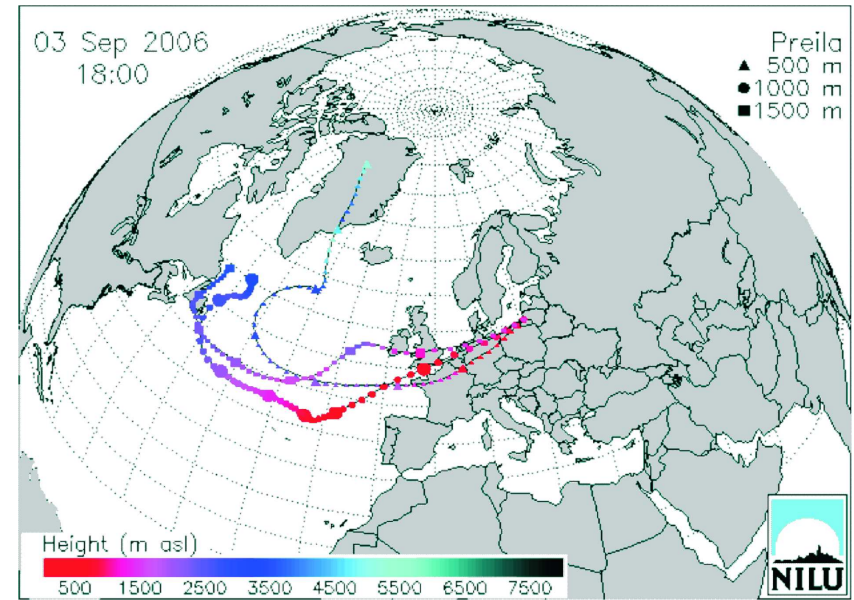

(a)

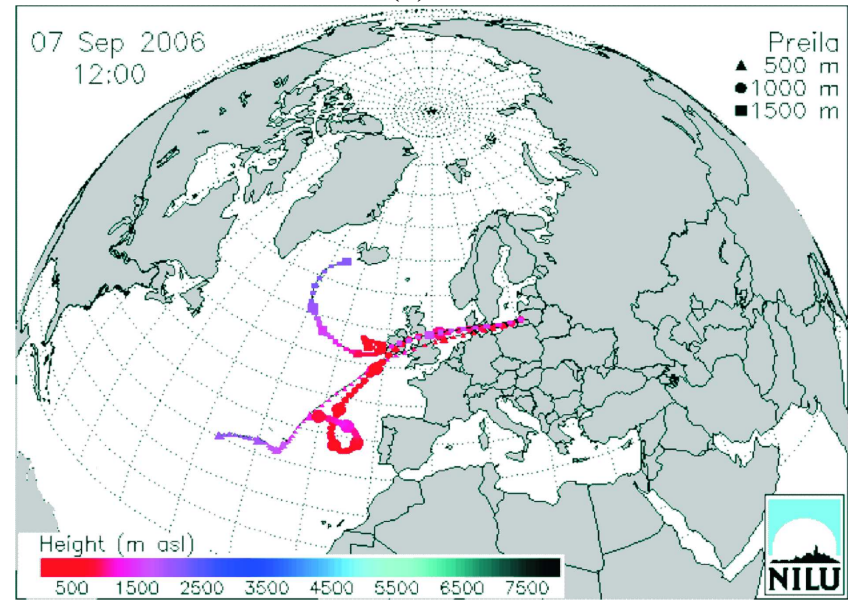

(c) eter detects the positive ion fragments generated by the electron impact ionization and determines the mass-tocharge $(\mathrm{m} / Z)$ distribution of the particle beam. Detailed descriptions of the AMS and its operation are given in publications [13, 14].

The AMS inlet system allows 100 percent trans-

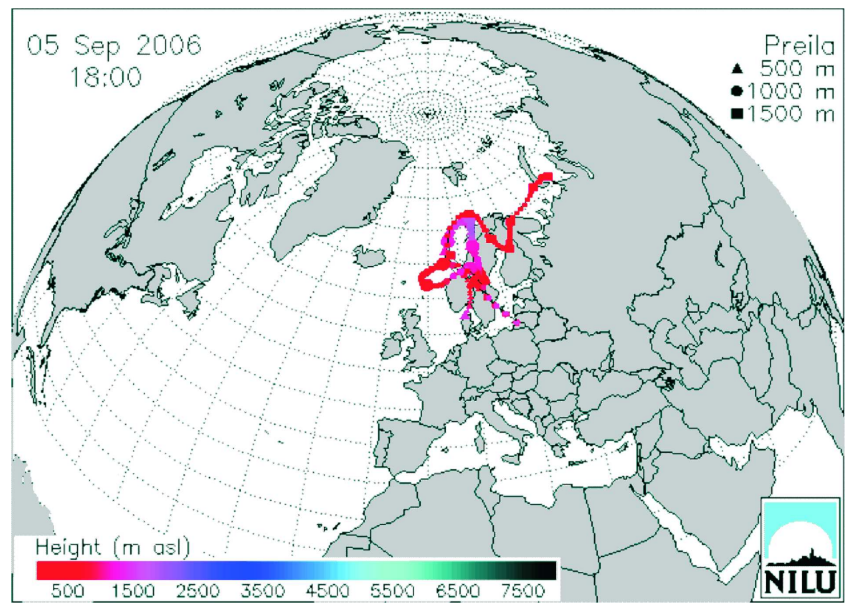

(b)

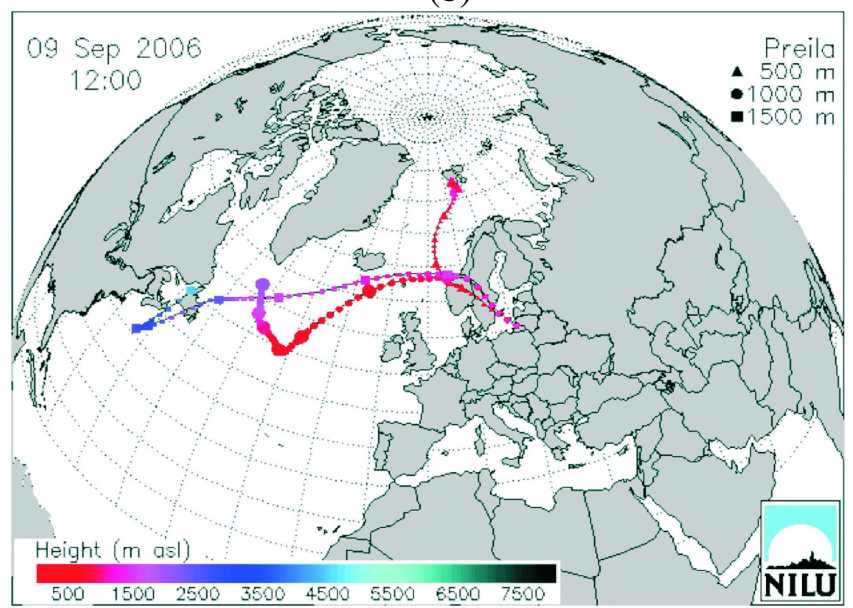

(d)

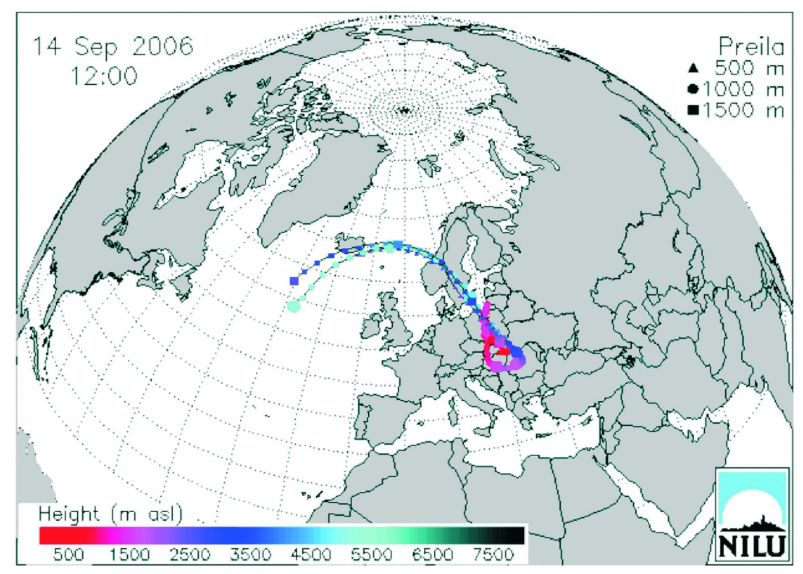

(e)

Fig. 2. Backward trajectories of air masses transport at the Preila station on (a) 3-4 September, (b) 5-6 September, (c) 7-8 September, (d) 9-10 September, (e) 14-15 September, 2006. 


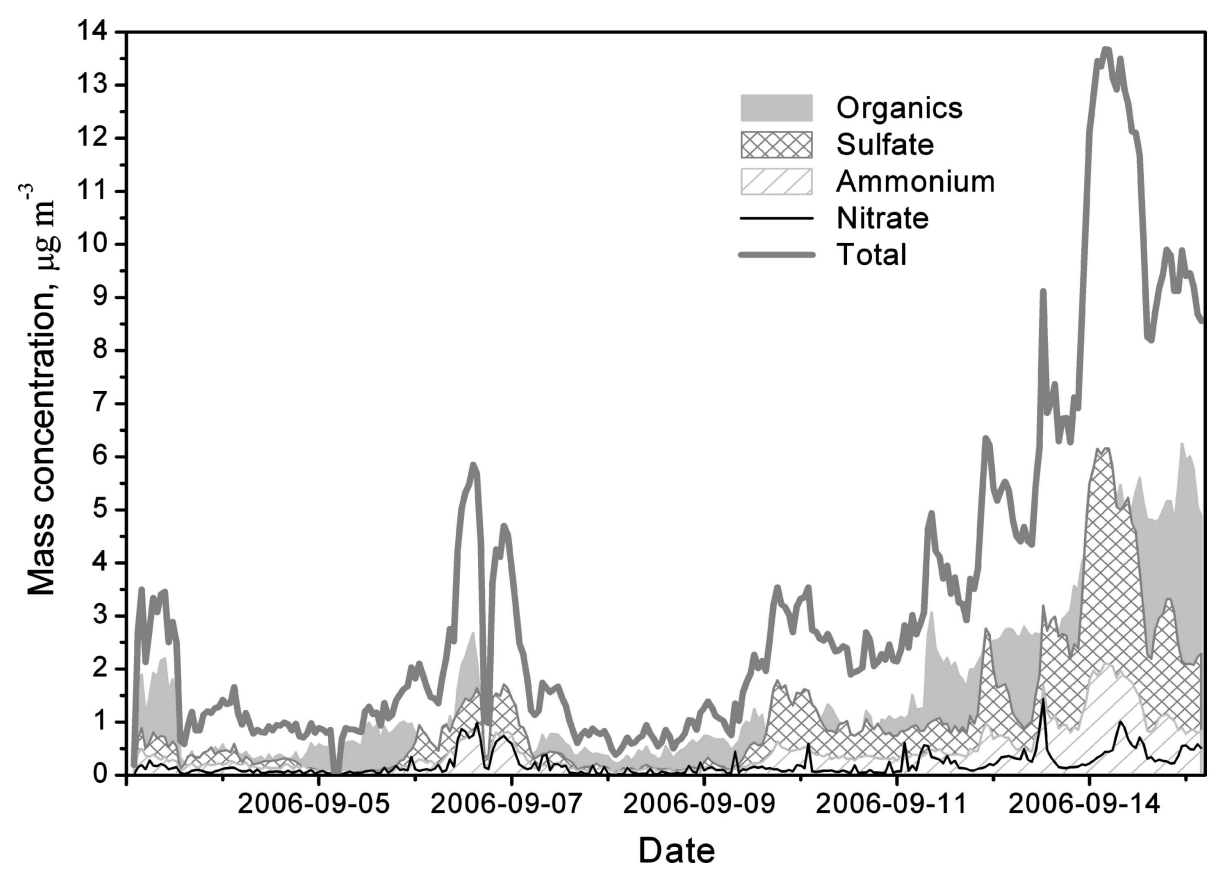

Fig. 3. Mass concentration of PM1 and its components.

mission efficiency for particles between 60 to $600 \mathrm{~nm}$ in diameter and particle transmission down to 20 and up to $200 \mathrm{~nm}$. The sensitivity of the device is $\sim 0.01 \mu \mathrm{g} \mathrm{m}^{-3}$ in several minutes. The sampling flow rate is $100 \mathrm{cc} \mathrm{min}^{-1}$. The device was calibrated by using ammonium nitrate particles of known size.

\subsection{Meteorological data}

Backward air mass transport trajectories were calculated using the FLEXTRA trajectory model from Norwegian Institute of Air Research (NILU, http:// www.nilu.no/trajectories/index.cfm) [15]. Trajectories were calculated for every $6 \mathrm{~h}$ with the total 7-day duration at three different altitudes: $1500,1000,500 \mathrm{~m}$ a.s.l. (Fig. 2).

\section{Results and discussion}

The major observed components of the aerosol particles in the range of PM1 were sulfate and organic compounds with a smaller amount of nitrate and ammonium (Fig. 3). Their concentration distribution depended on the air mass origin.

At the very beginning of this experiment (3-4 September) when the air masses were coming mainly from Western Europe (Fig. 2(a)), high concentrations of aerosol particles and their chemical components were measured (Fig. 3), especially organic matter. Later (5-6 September), when air masses were coming from Scandinavia, the concentration considerably decreased.

The general behaviour of the aerosol particles ( $\sim$ PM1) and concentration of their constituents were registered: concentrations were low when air masses were transported from the sea side, and concentrations instantly increased as soon as air mass turned from the continent. Furthermore, the sensitivity of AMS enabled us to register differences in composition and size in quite similar, at the first sight, air masses. For example, during two days (from 7 to 8 September) the air mass was generally from the clean oceanic sector, but it passed over England (Fig. 2(c)) and this considerably enhanced the total aerosol particle concentration and concentrations of their components, especially, sulfate and nitrate. But those concentrations were noticeably lower than concentrations registered when air mass had passed over Southern Europe (1315 September, Fig. 2(e)). Generally, measurements revealed large variations in concentrations of all chemical species ranging within an order of magnitude depending on the air mass origin and history.

The daily variation of $\sim$ PM1 or its components was not very pronounced (Fig. 4). However, different $\sim$ PM1 composition in different air masses showed separate sources. First of all, large contribution of organic matter was established in all air masses, but it reached $60 \%$ of the total aerosol particle mass in relatively clear Atlantic air masses (Fig. 4(a)). Such high concentration of organic matter is typical of the North 

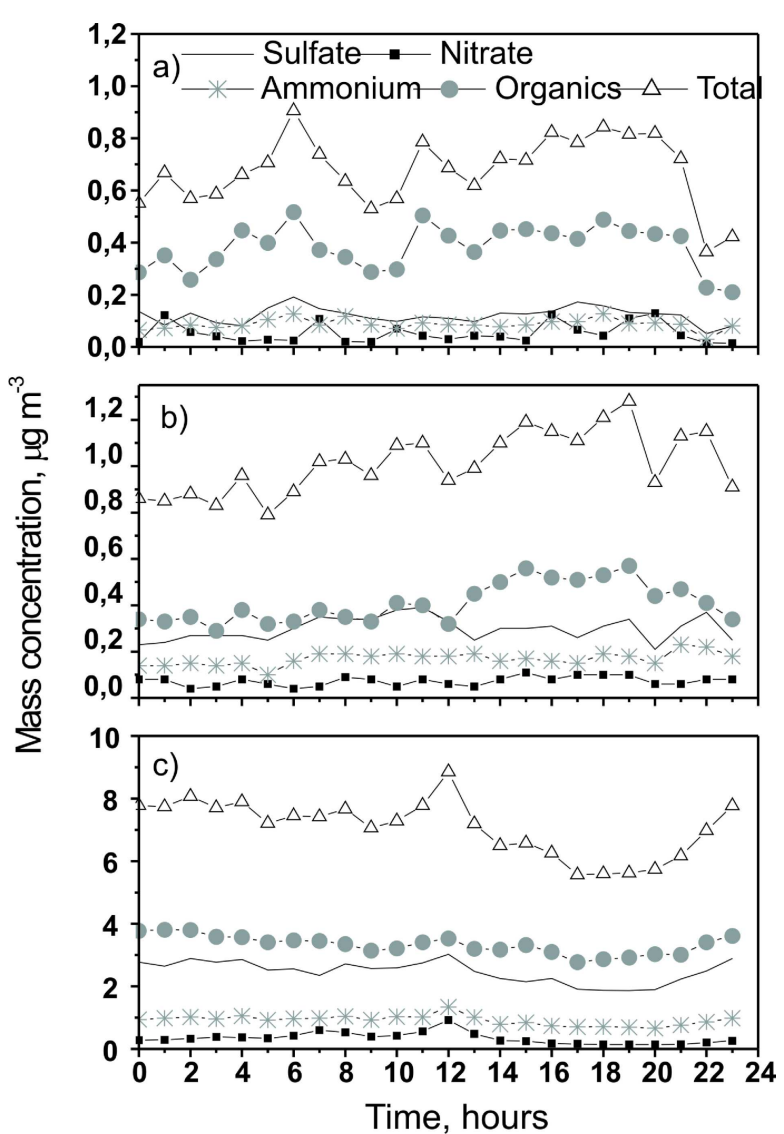

Fig. 4. Daily variations of concentration of PM1 and its components in different air masses: (a) Atlantic Ocean and Scandinavia (Fig. 2(d)); (b) Atlantic Ocean and part of Western Europe

(Fig. 2(a)); (c) Southern Europe (Fig. 2(e)).

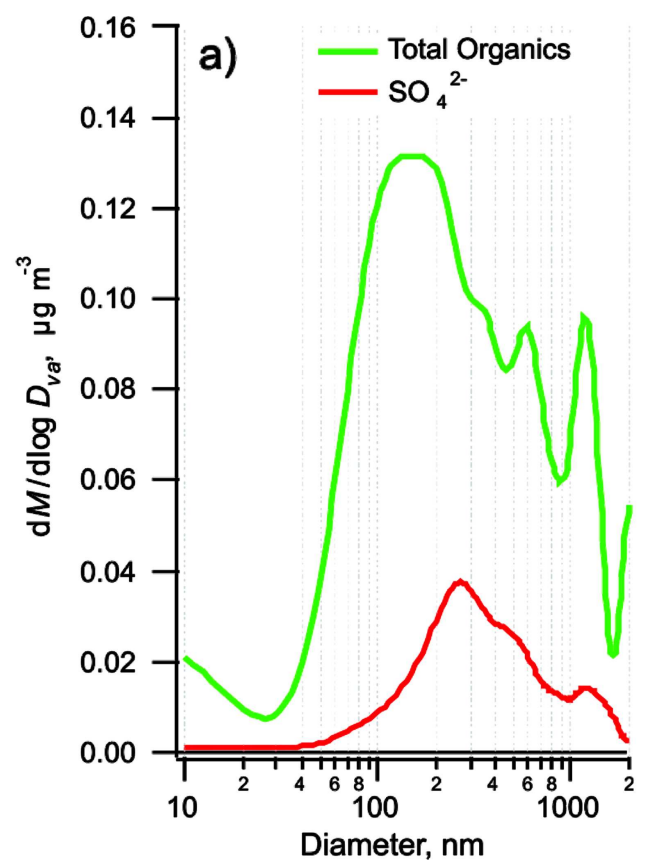

Atlantic air masses and these results have shown that natural organic compounds of marine origin reach continents and can have influence on aerosol particle composition there. The concentration of sulfate in marine air mass was quite low (Fig. 4(a)). This confirms quite a new theory presented to the scientific aerosol community that the impact on climate is determined by organic compounds rather than sulfate, as it was assumed previously. Even in polluted air masses (Fig. 4(c)), organic compounds made up 50\% of the all aerosol particle mass,

The analysis of size distribution spectra enabled us to explain the origin of aerosol chemical components. The difference between distribution of sulfate and organic compounds in relatively clean (Fig. 5(a)) and polluted (Fig. 5(b)) air masses as well as difference between sulfate and organic compound distributions in the same air mass were demonstrated. In relatively clear North Atlantic air mass, mainly two modes were registered, both for sulfate and organic compounds one in the submicron range, the other in the supermicron range. The diameter of sulfate-containing particles in the accumulation mode differed from that of organic-containing particels; they were about 270 and $170 \mathrm{~nm}$, respectively (Fig. 5(a)). Difference between diameters of sulfate and organic matter in relatively clear air mass suggests different sources or transformation mechanisms of these materials. Therefore, sulfate was formed by secondary processes but organic matter

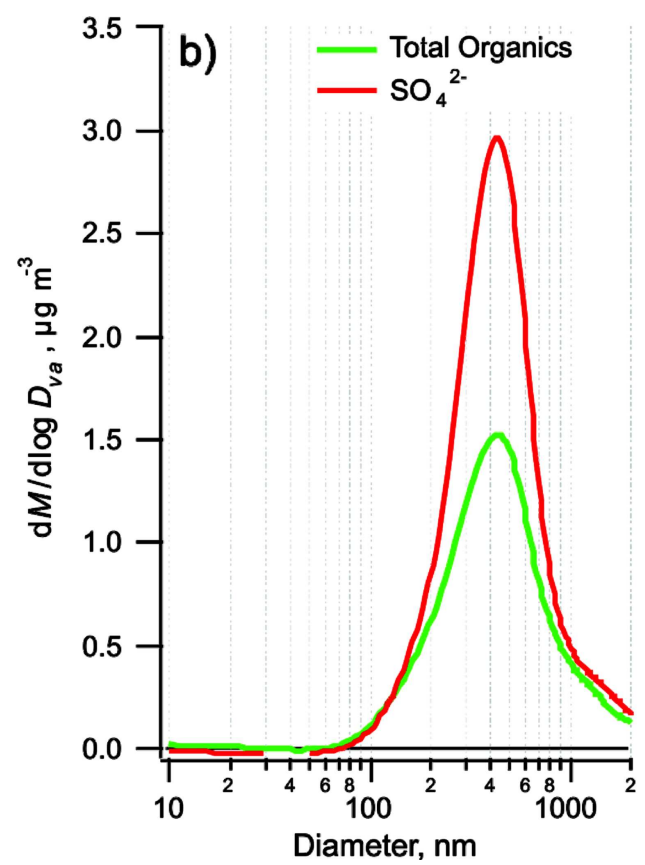

Fig. 5. Size distribution of sulfate and organic aerosol fractions (a) in relatively clear air mass from the North Atlantic Ocean and (b) in polluted air mass from Southern Europe. 
most likely had a different origin, probably originating primarily from the sea surface. In polluted air masses, the anthropogenic origin of both components was dominant, thus diameters in the accumulation mode became equal and were about $400 \mathrm{~nm}$, showing the same secondary production mechanisms including condensation of precursor gases onto existing particles.

\section{Conclusions}

The observed major components of the aerosol particles in the range of PM1 were sulfate and organic compounds with a smaller amount of nitrate and ammonium. Large contribution of organic matter was established in all air masses, but it reached $60 \%$ of the total aerosol particle mass in relatively clear Atlantic air masses.

In comparatively clear North Atlantic air mass, size distributions for sulfate and organic compounds were of two main modes: the submicron mode and the supermicron mode. The size distribution of sulfatecontaining particles and organic-containing particles in the accumulation mode differed in shape and had a mode diameter of about 270 and $170 \mathrm{~nm}$, respectively. This difference suggests different sources or transformation mechanisms of these materials. Therefore, sulfate was formed by secondary processes, but organic materials, supposedly, were formed primarily over the sea surface. In polluted air masses the size distribution of sulfate-containing particles and organic-containing particles was similar, the modal peaks of the sulfate and organic compounds became equal and were about $400 \mathrm{~nm}$, showing the same dominant secondary production mechanism.

\section{Acknowledgements}

This work was supported by the Lithuanian State Science and Studies Foundation under the project No. C-23/2005. We thank engineer J. Didžbalis (Institute of Physics, Lithuania) for technical assistance.

\section{References}

[1] D.W. Dockery, C.A. Pope, X. Xu, J.D. Spengler, J.H. Ware, M.E. Fay, B.G. Ferris, and F.E. Speizer, An association between air pollution and mortality in six U.S. cities, N. Engl. J. Med. 329, 1753-1759 (1993).

[2] R.J. Charlson, S.E. Schwartz, J.M. Hales, R.D. Cess, J.A. Coakley, J.E. Hansen, and D.J. Hofmann, Cli- mateforcing by anthropogenic aerosols, Science $\mathbf{2 5 5}$, 423-430 (1992).

[3] D. Čeburnis, J. Ovadnevaitè, K. Kvietkus, V. Remeikis, and V. Ulevičius, Aerosols, organic matter, and impact on climate, Lithuanian J. Phys. 45, 323-332 (2005).

[4] M. Hori, Role of organic aerosols in the activation of cloud condensation nuclei, J. Aerosol Res. 18, 257265 (2003).

[5] J.P. Putaud, F. Raes, R. Van Dingenen, E. Bruggemann, M.C. Facchini, S. Decesari, S. Fuzzi, R. Gehrig, C. Huglin, P. Laj, G. Lorbeer, W. Maenhaut, N. Mihalopoulos, K. Muller, X. Querol, S. Rodriguez, J. Schneider, G. Spindler, H. ten Brink, K. Torseth, and A. Wiedensohler, A European aerosol phenomenology-2: Chemical characteristics of particulate matter at kerbside, urban, rural and background site in Europe, Atmos. Environ. 38, 2579-2595 (2004).

[6] M. Kanakidou, J.H. Seinfeld, S.N. Pandis, I. Barnes, F.J. Dentener, M.C. Facchini, R. Van Dingenen, B. Ervens, A. Nenes, C.J. Nielsen, E. Swietlicki, J.P. Putaud, Y. Balkanski, S. Fuzzi, J. Horth, G.K. Moortgat, R. Winterhalter, C.E.L. Myhre, K. Tsigaridis, E. Vignati, E.G. Stephanou, and J. Wilson, Organic aerosol and global climate modeling: A review, Atmos. Chem. Phys. 5, 1053-1123 (2005).

[7] G.C. Roberts, M.O. Andreae, J. Zhou, and P. Artaxo, Cloud condensation nuclei in the Amazon basin: "Marine" conditions over a continent?, Geophys. Res. Lett. 28, 2807-2810 (2001).

[8] C.D. O’Dowd, M.C. Facchini, F. Cavalli, D. Čeburnis, M. Mircea, S. Decesari, S. Fuzzi, Y.J. Yoon, and J. Putaud, Biogenically driven organic contribution to marine aerosol, Nature 431, 676-680 (2004).

[9] L.M. Hildemann, W.F. Rogge, G.R. Cass, M.A. Mazurek, and B.R.T. Simoneit, Contribution of primary aerosol emissions from vegetation-derived sources to fine particle concentrations in Los Angeles, J. Geophys. Res. 101(D14), 19541-19549 (1996).

[10] P.H. McMurry, A review of atmospheric aerosol measurements, Atmos. Environ. 34, 1959-1999 (2000).

[11] P. Liu, P.J. Ziemann, D.B. Kittelson, and P.H. McMurry, Generating particle beams of controlled dimensions and divergence: I. Theory of particle motion in aerodynamic lenses and nozzle expansions. Aerosol Sci. Technol. 22, 293-313 (1995).

[12] X.F. Zhang, K.A. Smith, D.R. Worsnop, J. Jimenez, J.T. Jayne, and C.E. Kolb, A numerical characterization of particle beam collimation by an aerodynamic lens-nozzle system: Part I. An individual lens or nozzle, Aerosol Sci. Technol. 36, 617-631 (2002).

[13] J.T. Jayne, D.C. Leard, X.F. Zhang, P. Davidovits, K.A. Smith, C.E. Kolb, and D.R. Worsnop, Development of an aerosol mass spectrometer for size and composition analysis of submicron particles, Aerosol Sci. Technol. 33, 49-70 (2000). 
[14] J.L. Jimenez, J.T. Jayne, Q. Shi, C.E. Kolb, D.R. Worsnop, I. Yourshaw, J.H. Seinfeld, R. C. Flagan, X. Zhang, K.A. Smith, J.W. Morris, and P. Davidovits, Ambient aerosol sampling using the aerodyne aerosol mass spectrometer, J. Geophys. Res. 108(D7),
8425-8437 (2003).

[15] FLEXTRA trajectory model from Norwegian Institute of Air Research (NILU), http:// ww. nilu.no/trajectories/index.cfm.

\title{
SMULKIOSIOS AEROZOLIO DALELIU FRAKCIJOS CHEMINE் SUDE்TIS IR PASISKIRSTYMAS PAGAL DYDI RYTINĖJE BALTIJOS JŪROS PAKRANTĖJE
}

\author{
I. Rimšelytė ${ }^{\mathrm{a}}$, J. Ovadnevaité ${ }^{\mathrm{a}}$, D. Čeburnis ${ }^{\mathrm{a}, \mathrm{b}}$, K. Kvietkus ${ }^{\mathrm{a}}$, E. Pesliakaité ${ }^{\mathrm{a}}$ \\ ${ }^{a}$ Fizikos institutas, Vilnius, Lietuva \\ ${ }^{\mathrm{b}}$ Airijos nacionalinis universitetas, Galway, Airija
}

\section{Santrauka}

Preilos atmosferos užterštumo tyrimų stotyje $2006 \mathrm{~m}$. rugsèjo 3-15 dienomis, naudojant aerozolių masès spektrometrą (AMS), buvo atliekami aerozolio daleliu (apie PM1) cheminès sudèties bei pasiskirstymo pagal dydį tyrimai. Nustatyta, kad pagrindinès aerozolio dalelių sudedamosios dalys buvo sulfatai ir organinès medžiagos bei mažesni amonio ir nitratu kiekiai. Nors organinès medžiagos sudare žymią aerozolio dalelių dalị atneštose ị Preilą iš ịvairiu krypčiu oro masėse, tačiau sąlyginai švarioje oro masejje, ateinančioje nuo Šiaurès Atlanto, jų indèlis siekè net iki $60 \%$.

Atskiru aerozolio dalelèse esančių cheminių komponenčiu masès pasiskirstymo pagal dalelių dydị spektrai leidžia spręsti apie jų kilmę. Sąlyginai švarioje Šiaurès Atlanto oro masėje sulfatai ir organinès medžiagos stebètos submikroninès ir supermikroninès modos dalelèse. Šioje oro maseje akumuliacinès modos daleliụ diametrai sulfatams bei organinèms medžiagoms skyrėsi: sulfatams modos diametras buvo $\sim 270 \mathrm{~nm}$, o organinèms medžiagoms $\sim 170 \mathrm{~nm}$. Tai leidžia daryti prielaidą, jog sulfatai ir organinès medžiagos dalelèse atsirado skirtingu procesų metu, todèl ir jų kilmé skirtinga. Užterštoje oro masejje, atneštoje iš Pietų Europos, šių komponenčių akumuliacinès modos dalelių diametrai buvo vienodi (400 nm), o tai leidžia spręsti apie tą pačią (antropogeninę) jų prigimtị bei identiškus susidarymo mechanizmus. 